\title{
A Sensitive and Label-Free Electrochemical Impedance Immunosensor for CDH 22 Biomarker Detection Based on Organo-Functional Silane Modified ITO Electrode
}

\section{Organo-Fonksiyonel Silan ile Modifiye Edilmiş ITO Elektrot Temelli CDH 22 Biyobelirteç Tespiti için Hassas ve Etiketsiz Bir Elektrokimyasal İmpedans İmmünosensörü}

\section{Elif Burcu AYDIN*®}

Tekirdağ Namık Kemal University, Scientific and Technological Research Center, Tekirdağ, Turkey.

\section{A B STRACT}

\begin{abstract}
In this work, a novel electrochemical label free immunosensor was fabricated for Cadherin-like protein 22 (CDH 22) biomarker detection based on specific immunoreaction between anti-CDH 22 antibody and CDH 22 antigen. The developed immunosensor was constructed through the immobilization of anti-CDH 22 antibodies on 3-cyanopropyltrimethoxysilane (CPTMS) modified ITO substrate. The effective binding of the anti-CDH 22 antibodies on the CPTMS silanization agent was investigated by using morphological characterization (Scanning Electron Microscopy (SEM), Atomic Force Microscopy (AFM)) and electrochemical characterization (Electrochemical Impedance Spectroscopy (EIS), Cyclic Voltammetry (CV)). Under optimum experimental conditions, the ITO/CPTMS modified electrode was a good linker for anti-CDH 22 antibody anchoring. In addition, CPTMS modified electrode offered an efficient surface to CDH 22 antigen detection. The immunosensor had a wide linear detection range $(0.03-3 \mathrm{pg} / \mathrm{mL})$ with low detection limit $(9 \mathrm{fg} / \mathrm{mL})$. Also, it had good reproducibility, excellent repeatability and long storage stability. In addition, the practical applicability of the proposed immunosensor was investigated by utilizing human serum samples. The human serum samples recovery results $(99.16 \%-101.94 \%)$ illustrated the accuracy of the suggested biosensor. Consequently, CPTMS can be a promising platform for biosensor construction and this suggested immunosensor can be applicable for real human serum analysis.
\end{abstract}

Key Words

Cadherin-like protein 22, electrochemical impedance spectroscopy, disposable electrode.

\section{öz}

u çalışmada, anti-CDH 22 antikoru ve $\mathrm{CDH} 22$ antijeni arasındaki spesifik immüno-reaksiyona dayanan, kadherin benzeri protein (CDH 22) biyobelirtecinin tespiti için yeni bir elektrokimyasal etiketsiz immünosensör üretilmiştir. Geliştirilen immünosensör, anti-CDH 22 antikorlarının 3-siyanopropiltrimetoksisilan (CPTMS) ile modifiye edilmiş ITO substratı üzerinde immobilizasyonu ile oluşturulmuştur. Anti-CDH 22 antikorlarının CPTMS silanizasyon ajanına etkili bağlanması, morfolojik karakterizasyon (Taramalı Elektron Mikroskobu (SEM), Atomik Kuvvet Mikroskobu (AFM)) ve elektrokimyasal karakterizasyon (Elektrokimyasal Impedans Spektroskopisi (EIS), Siklik Voltammetri (CV) kullanılarak incelendi. Optimum deney koşulları altında, ITO / CPTMS ile modifiye edilmiş elektrot, anti-CDH 22 antikor bağlanması için iyi bir bağlayıcıydır. Ek olarak, CPTMS modifiye elektrot CDH 22 antijen tespiti için etkili bir yüzey sunmuştur. İmmünosensör, geniş bir lineer tespit aralığı (0.03-3 $\mathrm{pg} / \mathrm{mL}$ ) ile düşük tespit limiti $(9 \mathrm{fg} / \mathrm{mL})$ ile sahipti. Ayrıca, iyi tekrarlanabilirlik, mükemmel tekrarlanabilirlik ve uzun depolama kararlılığına sahipti. Ek olarak, önerilen immünosensörün pratik uygulanabilirliği, insan serum numuneleri kullanılarak araştırıldı. İnsan serum numuneleri geri kazanım sonuçları (\% 99.16 -\% 101.94) önerilen biyosensörün doğruluğunu göstermektedir. Sonuç olarak, CPTMS, biyosensör yapımı için umut verici bir platform olabilir ve bu önerilen immünosensör gerçek insan serum analizi için uygulanabilir.

\section{Anahtar Kelimeler}

Kadherin benzeri protein, elektrokimyasal impedans spektroskopisi, tek kullanımlık elektrot. 


\section{INTRODUCTION}

ancer threatens the human health and in the diagnosis of cancer, immunohistochemistry and flourescence methods are usually utilized [1, 2]. These methods require a lot of steps for cancer diagnosis and therefore, the analysis duration of these methods is long [3]. Biosensors are new devices for detection of biomolecules and specific biorecognition feature makes them reliable and rapid tools for medical applications. In biosensor designing different detection strategies have been utilized [4]. Electrochemical detection is mostly preferred due to high specificity and sensitivity. Biomarkers are biomolecules, which are found in human fluids and utilized for early detection of cancer. A lot of studies have been performed for biomarker detection by utilizing biosensors $[4,5]$.

Cadherin-like protein $22(\mathrm{CDH} 22)$ is a transmembrane glycoprotein. It is known as PB-cadherin and belongs to cadherin superfamily [6]. It has role in cell-cell adhesion and metastasis. $\mathrm{CDH} 22$ hypermethylation is an independent prognostic biomarker in breast cancer $[7,8]$. It is produced in the pituitary gland and brain. It helps to form tissue in neural and nonneural cells [6]. Over-expression of $\mathrm{CDH} 22$ results in colorectal cancer [6-8], breast cancer [7] and metastatic melanoma [8]. In addition, Cadherin-22 is a prognostic marker in advanced cancer stages and a potential factor in cancer metastasis or spread. The hindering of $\mathrm{CDH} 22$ biomarker decreases the adhesion and invasion rate of breast and brain cancer cells. Because of this, it has gained interest in diagnosis of breast cancer [9]. The detection of $\mathrm{CDH} 22$ biomarker is often carried out by utilizing ELISA kit. The linear range and detection limit of the ELISA kit are $15.6-500 \mathrm{ng} / \mathrm{mL}$ and $2 \mathrm{ng} / \mathrm{mL}$, respectively [9].

Indium tin oxide (ITO) is an excellent transparent semi-conductive substrate in different applications such as photovoltaic cell, optoelectronic devices and sensors. In sensor applications, it is utilized as a transducer owing to its unique optical transparency, broad working potential, stable electrochemical and physical features $[10,11]$. The selection of electrode for electrochemical immunosensing is important to develop sensitive immunosensor. Therefore, ITO is a favorable electrode material and has been employed as a working electrode in electrochemical sensors and biosensors. The effective anchoring of the biomolecules on the ITO substrate surface is a significant point to develop a successful biosensor. Therefore, several modification strategies such as physical adsorption [12], electrophoretic deposition [13-15], electrochemical deposition [16, 17], silanization [18, 19], self-assembled monolayer formation [20] and electro-polymerization [21-23] have been employed to develop ITO based biosensor. ITO substrates have been modified with different silane agents such as 3-isocyanatopropyl triethoxysilane (IPTES) [24], 3-aminopropyltriethoxy silane (APTES) [25-27], 11-cyanoundecyltrimethoxysilane (11-CUTMS) [28], (3-glycidoxypropyl)trimethoxysilane [29], N-(2-aminoethyl)-3aminopropyltrimethoxysilane [18], 3-mercaptopropyl trimethoxysilane (3-MPTMS) [30], 3-glycidoxy propyIdimethoxysilane [19], 11-(triethoxysilyl)undecanal (TESU) [31], carboxyethylsilanetriol (CTES) [32]. Silane agents form layers with terminal amino, epoxy or chloro groups. These groups are utilized for immobilization of biorecognition molecules. The basic principle of this technique is based on self-assembled monolayer (SAM) construction on the ITO substrate with hydroxyl ends. In this modification method, siloxane bonds are formed between hyroxylated ITO sheet surface and silane agent. Silane based SAMs provide a stable, reusable, reproducible and well-controlled surfaces for biomolecule attaching. In addition, the preparation of these layer is simple, and this layer prevents possible denaturation and non-specific adsorption. Cyanopropylsiloxanes are organosilane molecules and they have both polar and polarizable properties. Moreover, they have low surface tension, thus, they increase good surface wetting and the adhesion between dissimilar materials. They form interactions between the monolayer and the substrate which are used as binding platforms. The CPTMS silane agent includes a head group, an alkyl chain and an end group. The head group, trimethoxy- provides the attaching of the silane agent onto the platform. The alkyl chain increases the stability of the single layer owing to van der Waals interactions. The terminal group provides chemical groups to bind biomolecules [33, 34].

Electrochemical impedance spectroscopy (EIS) is a sensitive and an old electrochemical method utilized in biosensor characterization. It has gained interest due to informative features. This method is often employed to investigate the variations formed on the electrode surface due to antibody-antigen immune-interaction, probe DNA-target DNA interactions or enzyme-substrate reactions. The changes in electrode-electrolyte interface give information about the biosensing system. Additionally, impedance analyses are utilized in several 
electrochemical applications such as analysis of electrochemical kinetics of electrodes, batteries and sensors/biosensors [35-37]. It is also a successful way to characterize of modifications formed on the electrodes. By using this way, the detection of some analytes from small ions to large proteins is possible [38, 39]. Because of this, this method has been utilized for several analytes detection. In the impedance analysis, the biosensing system includes three electrodes; a working electrode (modified to investigate the target analyte), a counter electrode (for applying the electric current) and a reference electrode (for providing a reference value) [40]. This measurement way is sensitive and simple compared to other redox labelled electrochemical methods such as cyclic voltammetry (CV), differential pulse voltammetry (DPV) and square wave voltammetry (SWV) [41]. Electrochemically inert molecules can be measured by using EIS technique, during the analysis is carried out in the presence of redox couple (ferricyanide/ferrocyanide). In this technique, the oxidation and reduction reactions are formed at the electrode surface [42].

The goal of this work was a specific, sensitive and reproducible ITO based biosensor development for determination of $\mathrm{CDH} 22$ cancer marker. In the first step of the immunosensor fabrication, ITO sheet modified with CPTMS to form immobilization points for anti-CDH 22 antibodies. CPTMS was used for a self-assembled monolayer formation and it served as a link between ITO sheet and the biomolecule (anti-CDH 22 antibody). The variations formed on the immunosensor surface were investigated via cyclic voltammetry (CV) and EIS methods. The optimal experimental parameters were determined by performing a lot of experiments. The immunosensor analytical characterizations were performed under optimum experimental conditions. The repeatability, reproducibility and storage stability of the proposed immunosensor were also analyzed and discussed. This fabricated biosensor had a wide linear detection range (0.03-3 pg/mL) and low LOD $(9 \mathrm{fg} / \mathrm{mL})$. In addition, the practical applicability of the proposed immunosensor was investigated by utilizing human serum samples. The human serum samples results illustrated the accuracy of the suggested biosensor. The EIS responses indicated that $\mathrm{CDH} 22$ antigens could be detected simply and sensitively by this new biosensor. Moreover, the immunosensor responses demonstrated that the fabricated biosensor could be employed to detect $\mathrm{CDH} 22$ antigen in human serum samples.

\section{MATERIALS and METHODS}

\section{Reagents}

ITO coated Polyethylene Terephthalate (PET) films (resistance and thickness are $60 \Omega$ /square and $150 \mathrm{~nm}$ ), 3-cyanopropyltrimethoxysilane (CPTMS), toluene, Monoclonal anti-CDH 22 antibody, $\mathrm{CDH} 22$ antigen and BSA were supplied by Sigma-Aldrich. Dilutions of anti-CDH 22 antibodies and $\mathrm{CDH} 22$ antigens were prepared with PBS buffer (pH 7.4, 50 mM) before use. Ferri-ferro solution was utilized as a redox couple and prepared by utilizing $5 \mathrm{mM} \mathrm{K}_{4}\left[\mathrm{Fe}(\mathrm{CN})_{6}\right] / \mathrm{K}_{3}\left[\mathrm{Fe}(\mathrm{CN})_{6}\right]$.

\section{Apparatus}

Electrochemical analyses were recorded with Gamry 1000 Potentiostat/Galvanostat. Disposable ITO sheet (2*20 mm), $\mathrm{Ag} / \mathrm{AgCl}$ electrode, and platinum wire were utilized as working, reference and counter electrode, respectively. Two different electrochemical methods were employed: EIS and CV. All the analyses were carried out at room conditions using a $5 \mathrm{mM}$ redox couple solution of $\mathrm{K}_{3} \mathrm{Fe}(\mathrm{CN})_{6} / \mathrm{K}_{4} \mathrm{Fe}(\mathrm{CN})_{6}$. In the EIS experiments the frequency range was from 0.05 to $50 \mathrm{KHz}$. The working conditions for $\mathrm{CV}$ analyses were as follows; scan rate: $100 \mathrm{mVs}^{-1}$ and step size $10 \mathrm{mV}$. The surface topography during biosensor fabrication steps was investigated by using FEI-Quanta FEG 250 Model SEM microscope at an operating voltage $5 \mathrm{kV}$. AFM images were recorded utilizing a NanoMagnetics InstrumentsAFM Plus Model. All AFM images were taken in tapping mode with a tapping silicon tip and the tip radius was $<10 \mathrm{~nm}$. In order to follow the side groups formed on the ITO electrode, FTIR (Bruker Vertex 70 ATR Model) and Raman Spectroscopy (Thermo DXR Raman spectrometer equipped with a 780-nm excitation laser) was employed.

\section{Modification of ITO Electrodes for CDH 22 Antigen Detection}

Before the modification of ITO electrodes, they were cleaned in ultrasonic bath with ethanol, soap solution and ultrapure water, respectively. After cleaning, they were immersed in a mix solution of $\mathrm{H}_{2} \mathrm{O}_{2} / \mathrm{NH}_{4} \mathrm{OH} / \mathrm{H}_{2} \mathrm{O}$ (1:1:5) for $90 \mathrm{~min}$ at room conditions to form hydroxyl end on the ITO electrode surfaces. Then, they were washed with ultrapure water and were dried under argon gas. The silanization of ITO sheets were performed by immersing in 0.5\% CPTMS solution (prepared 


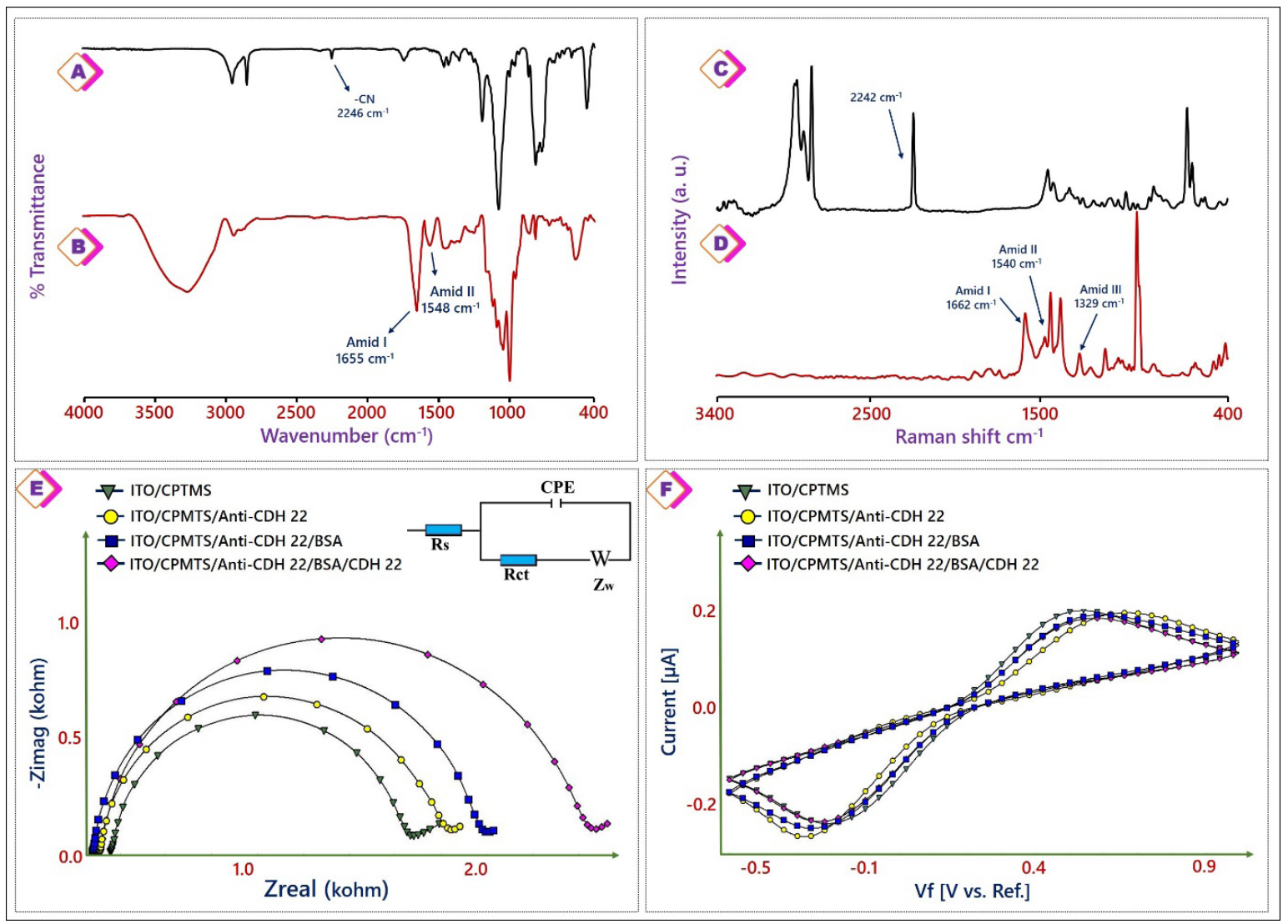

Figure 1. FTIR spectra and Raman spectra of CPTMS functionalized ITO substrate ( $A$ and $C$ ) and after anti-CDH 22 anchoring on the working electrode ( $B$ and $D)$, Nyquist plots $(E)$ and $C V s(F)$ of the $C D H 22$ biosensor of the immune-electrode construction stage; Randle's equivalent circuit (inset).

by using touene) for overnight. After CPTMS layer formation on the ITO sheets, they were washed with toluene and ultrapure water to eliminate the nonattached silane molecules and dried under argon gas. Afterwards, anti-CDH 22 antibody immobilization was performed by incubation in anti-CDH 22 antibody solution (2 ng/ $\mathrm{mL}$ ). The nonattached antibody molecules removed by washing ultrapure water. Finally, the remaining cyano groups of CPTMS were blocked by utilizing BSA protein After these steps, ITO electrodes could be used for $\mathrm{CDH}$ 22 antigen detection.

\section{Human Serum Sample Measurements}

Human serum samples were supplied by the Tekirdağ Namık Kemal University Faculty of Medicine. CDH 22 antigen measurements were performed after a 100000 fold dilution with phosphate buffer $(50 \mathrm{mM}, \mathrm{pH}$ 7.4). The success of the suggested biosensor was investigated by addition of $\mathrm{CDH} 22$ antigen to the diluted human serum samples.

\section{RESULTS and DISCUSSION}

\section{Chemical Characterization of the Immunosensor}

In this work, the FTIR and Raman Spectrometers were utilized to investigate the chemical bonds between cyano groups of CPTMS present on the ITO substrate and amino ends of anti-CDH 22 antibodies. The FTIR spectra of CPTMS functionalized ITO substrate and anti-CDH 22 antibody attached ITO substrate are displayed in Figure $1 \mathrm{~A}$ and Figure $1 \mathrm{~B}$, respectively.

The FTIR spectra of CPTMS functionalized ITO substrate (Figure 1A) showed the characteristic absorption peak at $2246 \mathrm{~cm}^{-1}(-\mathrm{C} \equiv \mathrm{N})$, that proved the CPTMS SAMs were formed completely [43-45]. As seen Figure 1B, the FTIR spectrum illustrated that the amino ends were introduced on the CPTMS functionalized ITO substrate. The peak at $1655 \mathrm{~cm}^{-1}$ and $1548 \mathrm{~cm}^{-1}$ in the FTIR spectrum of anti-CDH 22 antibody immobilized disposable ITO substrate proved that amino ends were present on the working electrode [28]. In addition to FTIR analysis, Ra- 


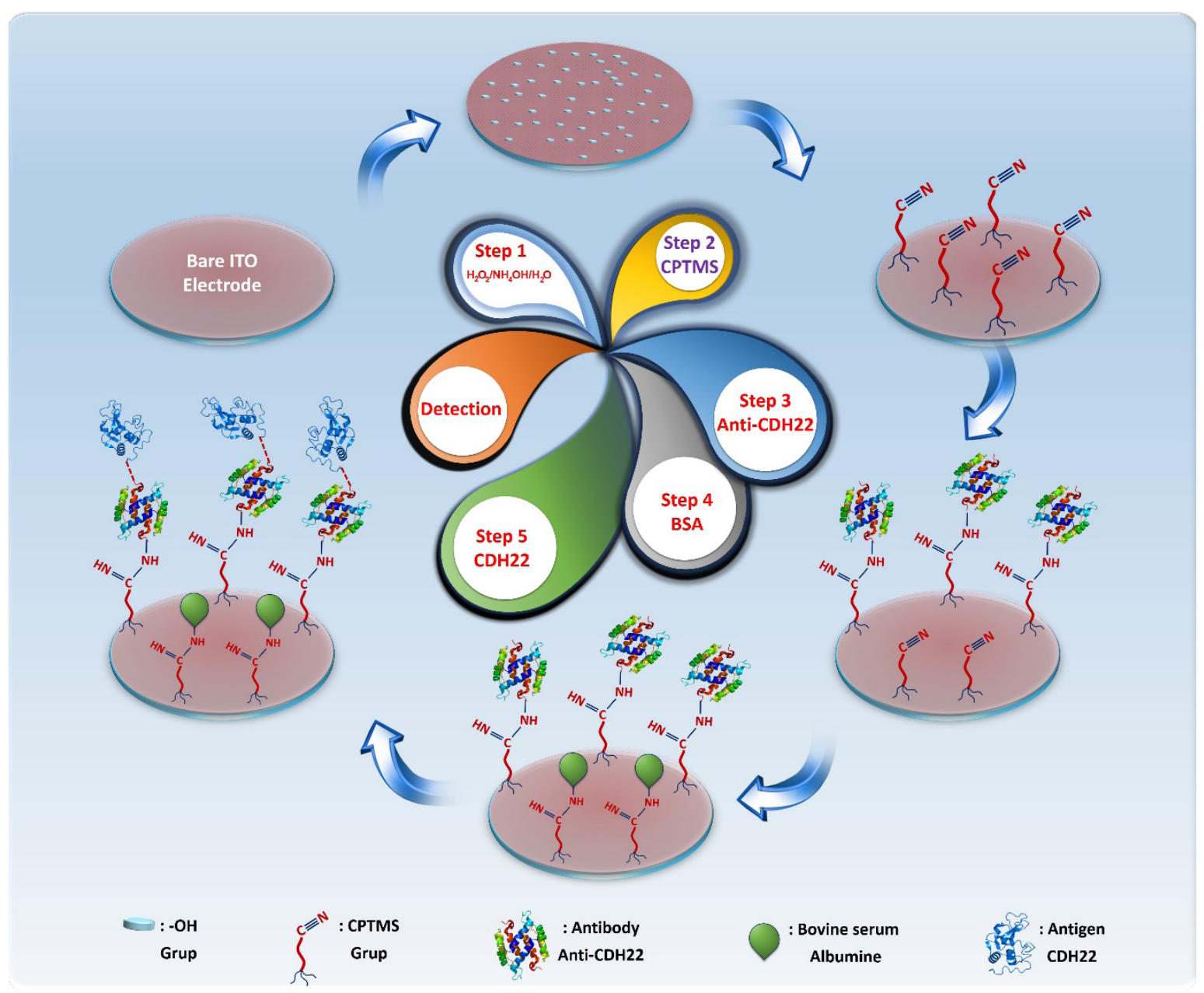

Scheme 1. Schematic illustration of biosensor fabrication steps and electrochemical detection of CDH 22 antigen.

man spectrometer was utilized for the chemical characterization. Raman spectroscopy is a useful technique to investigate of chemical binding of proteins, nucleic acids, large molecules. In the FTIR spectra of proteins and nucleic acids are complicated and many bands are overlapped. The Raman spectra of CPTMS functionalized ITO substrate and anti-CDH 22 antibody attached ITO substrate are displayed in Figure $1 \mathrm{C}$ and Figure 1D, respectively. As seen in Figure $1 \mathrm{C}$, the cyano group of CPTMS was observed at $2242 \mathrm{~cm}^{-1}$. Amide I, II and III regions are usually observed between 1650-1680 $\mathrm{cm}^{-1}, 1480-1570 \mathrm{~cm}^{-1}$ and $1235-1300 \mathrm{~cm}^{-1}$, respectively. As shown in Figure 1D, amide I, amide II and amide III bonds were observed at 1662, 1540 and $1329 \mathrm{~cm}^{-1}$, respectively.

\section{Electrochemical Characterization of the Fabrication Procedure}

The $\mathrm{CDH} 22$ immunosensor fabrication stages are illustrated in Scheme 1. ITO electrode surface was hydroxy- lated by $\mathrm{H}_{2} \mathrm{O}_{2} / \mathrm{NH}_{4} \mathrm{OH} / \mathrm{H}_{2} \mathrm{O}$ solution and CPTMS linked to hydroxyl ends on the ITO electrode surface via siloxane bonds. In this way, a biomolecule immobilization matrix was formed on the disposable ITO sheet. CPTMS provided free cyano ends on the ITO sheet surface allowing the covalent binding of $\mathrm{NH}_{2}$ groups of anti-CDH 22 antibodies. After antibodies binding on the modified ITO electrode, the free cyano groups blocked by BSA. After that, the immunosensor was utilized for $\mathrm{CDH} 22$ antigen detection.

The modification steps of the $\mathrm{CDH} 22$ biosensor was investigated by EIS and CV analyses. EIS is a powerful method for investigation of the electrode interface properties. $\left[\mathrm{Fe}(\mathrm{CN})_{6}^{3-14-]}\right.$ was a redox active couple and utilized for monitoring electrochemical features of the proposed immunosensor [43]. Figure 1E shows the Nyquist plots after modification steps. Nyquist plots of the modified ITO electrodes contain a semicircle portion and a linear portion. A semicircle part and a linear part are 

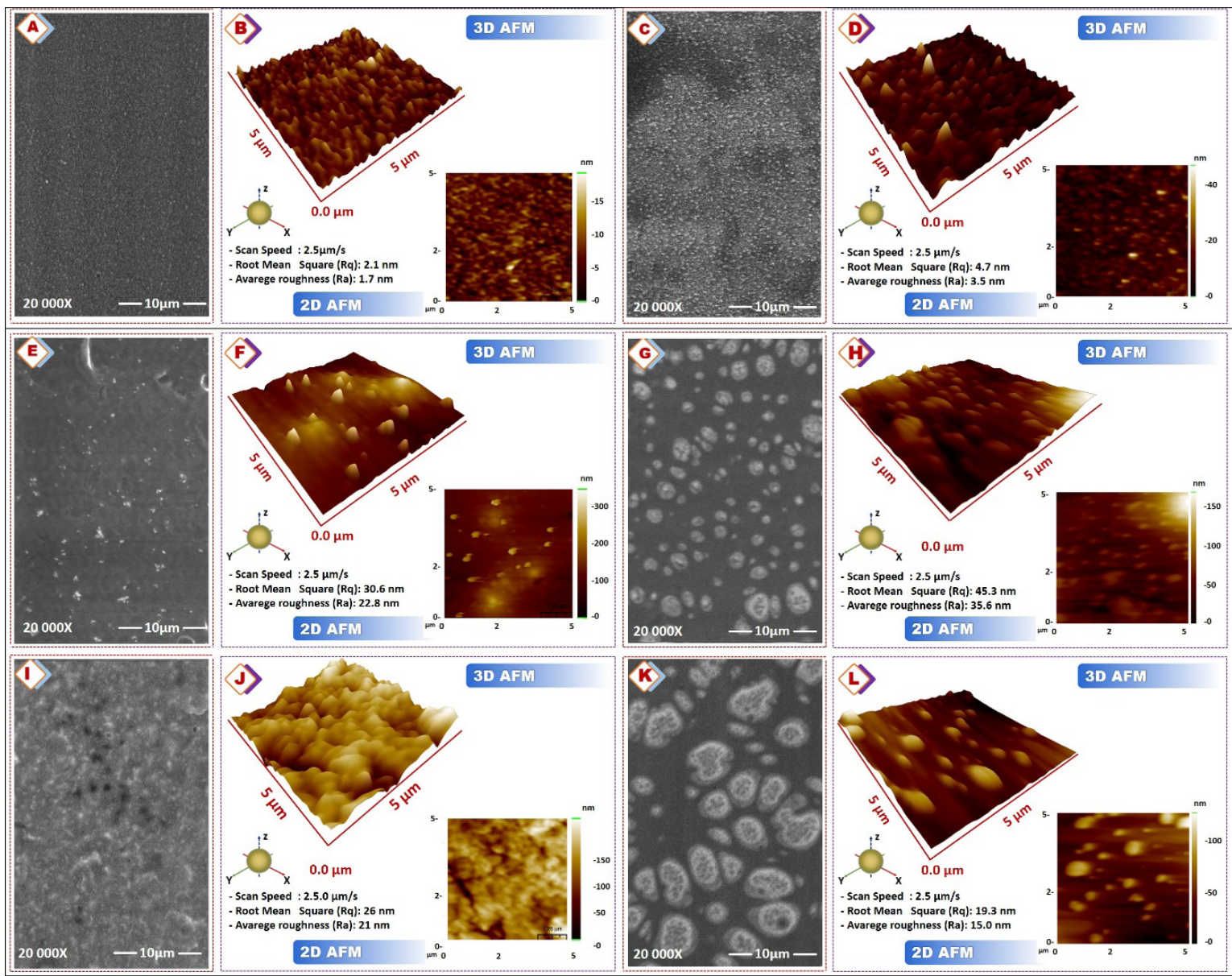

Figure 2. SEM and AFM images of bare ITO ( $A$ and $B$ ), ITO/OH (C and D), ITO/CPTMS (E, and F), ITO/CPTMS/anti-CDH 22 (G and H), ITO/ CPTMS/anti-CDH 22/BSA (I and J), ITO/CPTMS/anti-CDH 22/BSA/CDH 22 (K and L).

obtained at higher frequencies and at lower frequencies, respectively. The semicircle part and the linear part are related to electron transfer and diffusion processes, respectively. The semicircle diameter is responsible for the electron transfer resistance (Rct). The variations in Rct value is associated with the blocking effect of the step-by-step fabrication process of the immmunosensor. The impedance responses are fitted to the Randle's equivalent circuit. It contains the ohmic resistance of the electrolyte solution (Rs), constant phase element (CPE), Warburg impedance (Zw) and charge transfer resistance (Rct) (Figure 1E inset). Under ideal conditions, Zw and Rs illustrate the properties of the electrolyte solution and diffusion of the redox couple, therefore to they are not affected from electrode modification steps. Additionally, CPE and Rct display the dielectric and insulating features at the electrode/electrolyte interface and the variations occurred on the electrode surfaces affects them $[44,45]$.
Electrochemical characterizations with CV and EIS methods are useful to evaluate the electrochemical process on the modified surfaces. The CVs and EIS spectra were shown in Figure 1 to illustrate the electrochemical behavior of the ITO surface during the immunosensor fabrication. As shown in Figure 1E, ITO/CPTMS electrode had small semicircle diameter that indicated easy electron transfer between electrode surface and electrolyte solution. After anti-CDH 22 antibody immobilization on the CPTMS modified ITO substrate, an increase was seen in semicircle diameter. The immobilization of antibodies caused a layer formation on the ITO substrate surface. Thus, the electron transfer rate was decreased. In the BSA blockage step, electron transfer was obstructed, and an increase was seen in semicircle diameter. The specific immuno-reaction between anti-CDH 22 antibody and $\mathrm{CDH} 22$ antigen formed a immunocomplex and a large semicircle diameter was seen. Compared 
to hydroxylated ITO surface, the CPTMS modified ITO electrode surface had lower peak currents (Figure 1F). This result confirmed the CPTMS SAMs on the ITO substrate surface. After anti-CDH22 antibody, BSA and CDH 22 antigen immobilization, peak currents were decreased due to nonconductive layers formation on the electrode surface. These layers prevented the electron transfer between ITO electrode surface and electrolyte solution. In other words, these layers illustrated hindrance effects to electron transfer.

\section{Morphological Characterization of the Fabrication Steps}

The morphological characterization of the proposed immunosensor was performed AFM and SEM imaging. Figure 2 illustrates images of the proposed immunosensor surfaces during the fabrication. After cleaning of ITO sheet, a smooth surface was obtained (Figure 2A and Figure $2 B$ ). In this step, the average roughness (Ra) was measured as $1.7 \mathrm{~nm}$ on a $5 \times 5 \mu \mathrm{m}$ scale. The hydroxylation of clean ITO sheet increased the roughness of ITO surface (Figure 2D). As seen in figure $2 \mathrm{C}$, this process changed the electrode surface. After hydroxylation, the average roughness ( $\mathrm{Ra}$ ) was measured as $3.5 \mathrm{~nm}$ on a $5 \times 5 \mu \mathrm{m}$ scale. As mentioned above, Self-assembled monolayer formation technique was utilized for biorecognition molecule immobilization. In this study, CPTMS was used as linker for anti-CDH 22 antibody anchoring, The SEM and AFM images illustrated that a uniform CPTMS SAMs formation on the ITO electrode in Figure $2 \mathrm{E}$ and Figure $2 \mathrm{~F}$, respectively. The average roughness (Ra) was measured as $22.8 \mathrm{~nm}$ on a $5 \times 5 \mu \mathrm{m}$ scale. The variations on the ITO substrate surface after anti-CDH 22 antibody attaching are displayed in Figure $2 \mathrm{G}$ and $\mathrm{Fi}$ gure $2 \mathrm{H}$. It can be clearly seen that the anti-CDH 22 antibodies were linked on the substrate and they looked like granules. In this step, the Ra value was measured as $88 \mathrm{~nm}$ on a $5 \times 5 \mu \mathrm{m}$ scale. At the BSA blockage step, the surface morphology of the ITO substrate was changed as observed in Figure $2 \mathrm{I}$ and Figure 2J. After BSA immobilization, the Ra value was measured as $21 \mathrm{~nm}$ on $5 \times 5 \mu \mathrm{m}$ scale. Figure $2 \mathrm{~K}$ and Figure $2 \mathrm{~L}$ display the SEM and AFM images of specific immuno-reaction between anti-CDH 22 antibodies and CDH 22 antigens. As seen in SEM image (Figure 2K), the surface was changed and it was in accord with AFM observation. The Ra value was measured as $126 \mathrm{~nm}$ on $5 \times 5 \mu \mathrm{m}$ scale (Figure $2 \mathrm{~L}$ ).
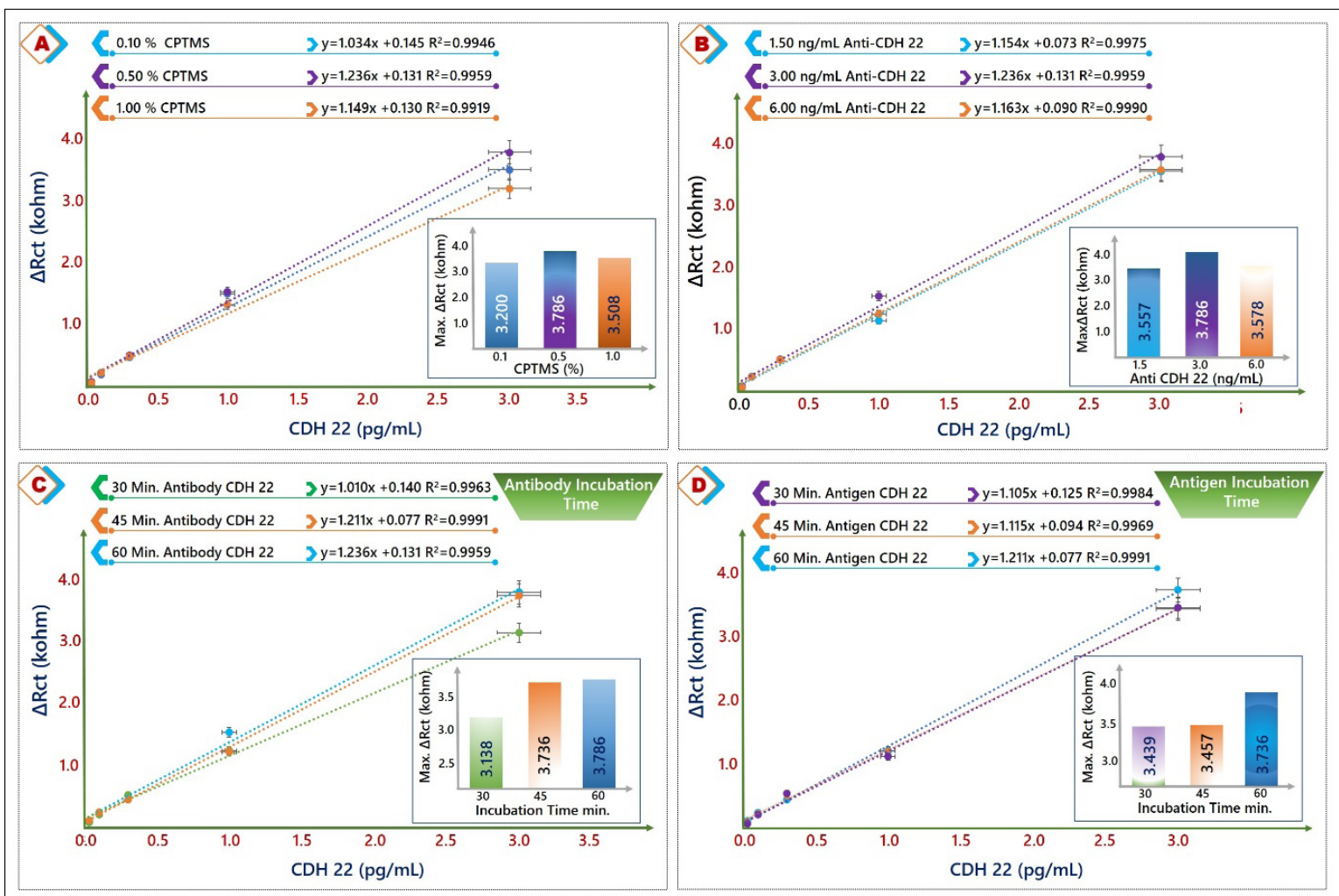

Figure 3. Optimization results (A) CPTMS quantity, (B) anti- CDH 22 antibody level, (C) anti-CDH 22 antibody incubation duration, (D) $\mathrm{CDH} 22$ antigen incubation duration. 


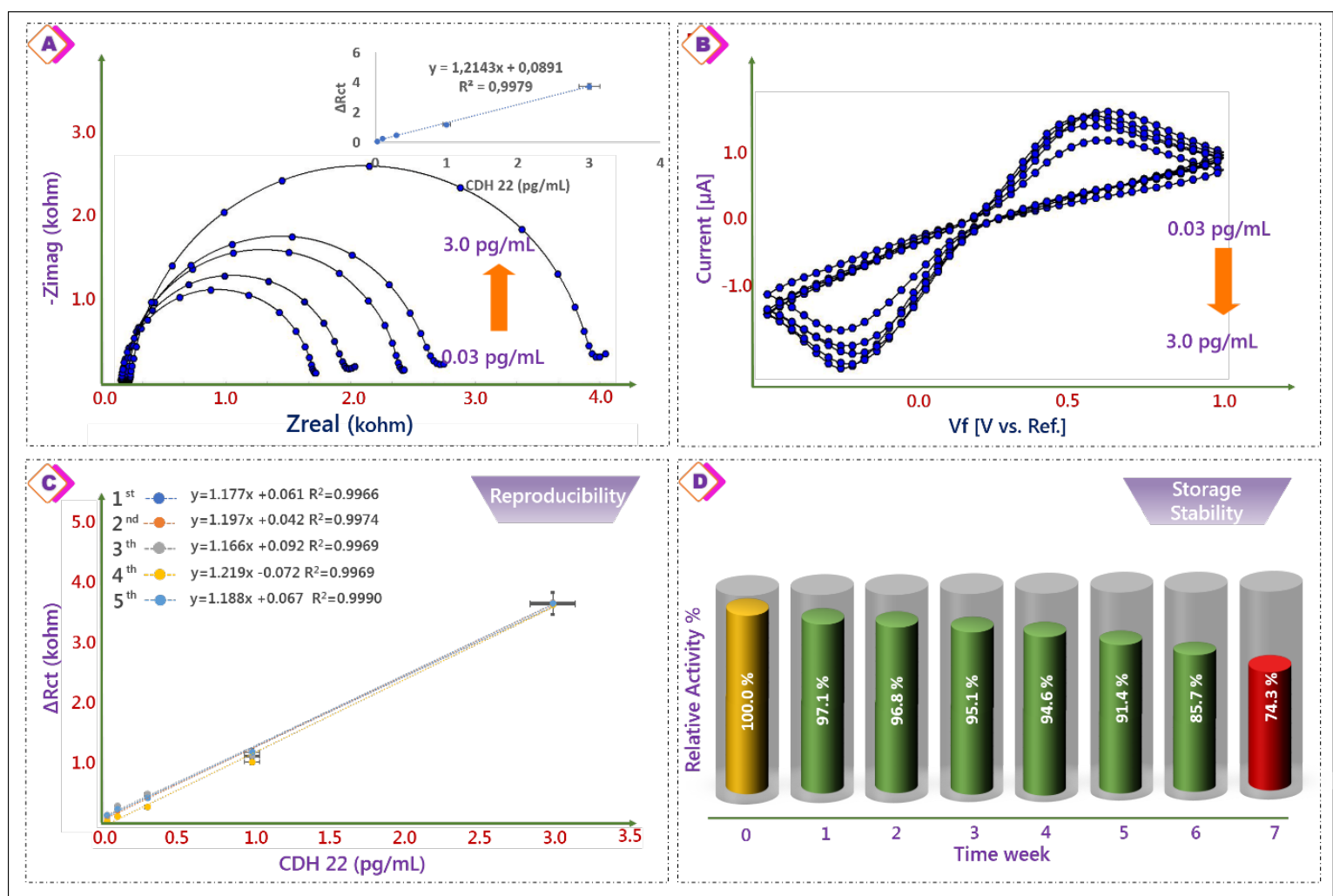

Figure 4. $\mathrm{EIS}(\mathrm{A})$ and $\mathrm{CV}(\mathrm{B})$ results of the biosensor for the determination of $\mathrm{CDH} 22$ biomarker (from 0.03 to $3 \mathrm{pg} / \mathrm{mL}$ ), calibration plot (inset). Reproducibility (C), Storage stability (D) of the biosensor.

\section{Optimization of Experimental Conditions}

In order to determine optimal experimental conditions, a variety of experiments were performed. The optimization of these parameters provided a sensitive and stable biosensor fabrication. In this work, CPTMS concentration, anti-CDH 22 antibody level, anti-CDH 22 antibody incubation duration and CDH 22 antigen incubation duration were optimized. These analyses were performed at room conditions and these parameters were followed by EIS and CV.

In the first stage of the experimental conditions optimization, the utilized CPTMS concentration was optimized. This stage had a significant role in the binding of adequate amount of anti-CDH 22 antibodies. Because of this, three different amounts (0.1\%; $0.5 \% ; 1 \% \mathrm{w} / \mathrm{w}$ ) were studied. Silane ends of CPTMS bound to hydroxyl group of hydroxylated ITO electrode. The low CPTMS level caused low immunosensor response because, a stable SAMs was not formed. The high CPTMS levels $(0.5 \%$ and $1 \%)$ caused similar immunosensor signals. The highest signal was achieved after utilizing $0.5 \%$ concentration of CPTMS. The responses of the immunosensors that obtained after usage of these levels were utilized to drawn of the linear curves. These linear curves are illustrated in Figure 3A. Then, anti-CDH 22 antibody level was optimized. This stage had a significant role in analytical performance of the proposed immunosensor. In order to select optimal anti-CDH 22 antibody level, $1.5 \mathrm{ng} / \mathrm{mL}$, $3 \mathrm{ng} / \mathrm{mL}$ and $6 \mathrm{ng} / \mathrm{mL}$ anti-CDH 22 antibody concentrations were tried. The highest $\Delta$ Rct value was found at $3 \mathrm{ng} / \mathrm{mL}$ anti-CDH 22 concentration. Because of this, 3 $\mathrm{ng} / \mathrm{mL}$ anti-CDH 22 level was selected optimal antibody level. The calibration plots of these levels are displayed in Figure 3B. To determine the optimal CDH 22 antibody incubation time, CPTMS functionalized ITO sheets incubated in anti-CDH 22 antibody solution for 30, 45 and $60 \mathrm{~min}$. The highest response was found after 60 min incubation, but the response at 45 min incubation time was nearly same. Therefore, 45 min was selected as the optimal incubation time for antibody anchoring. The short preparation period of the immunoelectrode provides a short fabrication process of the proposed immunosensor. The calibration plots of the different incubation times are displayed in Figure 3C. Lastly, the immunoreaction period between anti-CDH22 antibody and $\mathrm{CDH} 22$ antigen was optimized. At this step, the prepared immunoelectvrodes were immersed in $\mathrm{CDH}$ 
22 antigen solution for three different times (30 min, 45 $\mathrm{min}, 60 \mathrm{~min}$ ). The maximum immunosensor response was obtained after 60 min incubation. The other signals were nearly same and low. Because of this, 60 min was optimum incubation time (Figure 3D).

\section{Electrochemical Detection of CDH 22 Antigen}

Electrochemical detection of $\mathrm{CDH} 22$ antigen was achieved by CV and EIS analyses in the presence of redox system. Figure 4 illustrates the EIS and CV responses of the immunosensor at the increasing concentration of $\mathrm{CDH} 22$ antigens. The increasing concentration of $\mathrm{CDH}$ 22 antigens caused gradual increases in impedance responses (Figure 4A) and gradual decreases in CVs (Figure $4 \mathrm{~B}$ ). Also, these responses showed that these antigens formed a blocking wall, and lead to higher electrochemical resistances and lower peak currents. Also, an increase in Rct value was observed as the concentration of $\mathrm{CDH} 22$ antigen concentration increased from $0.03 \mathrm{pg} /$ $\mathrm{mL}$ to $3 \mathrm{pg} / \mathrm{mL}$ (Figure $4 \mathrm{~A}$ inset). The limit of detection (LOD) was estimated to be $9 \mathrm{fg} / \mathrm{mL}$ based on the $3 \sigma$ rule. The limit of quantification (LOQ) was calculated to be 30 $\mathrm{fg} / \mathrm{mL}$ based on the $10 \sigma$ rule.

\section{Repeatability, Reproducibility and Stability}

The repeatability of the proposed immunosensor was evaluated by measuring $\mathrm{CDH} 22$ concentration $(0.3 \mathrm{pg} /$ $\mathrm{mL}$ ) with 10 different bioelectrodes prepared under identical conditions. The relative standard deviation (RSD) was measured as $2.17 \%$. The reproducibility of the suggested immunosensor was investigated by measuring $\mathrm{CDH} 22$ concentration with 5 different biosensing system. Under the identical experimental conditions, the RSD was measured as $1.50 \%$ (Figure 4C). These obtained results indicated an excellent precision and good reproducibility of the prepared immunosensor.
The stability of the $\mathrm{CDH} 22$ immunosensor was also investigated. The immunosensor was stored at $4^{\circ} \mathrm{C}$ for 10 weeks. During the storage period, a gradually decrease was seen in the impedance response. After 7 weeks of storage, the impedance response of the CDH $22 \mathrm{immu}$ nosensor decreased $74.3 \%$ of its initial activity, showing that the immunosensor could keep its activity for a long time (Figure 4D).

\section{Analysis of Real Human Serum Samples}

In order to verify the applicability of suggested immunosensor, the prepared immunoelectrodes were utilized for human serum sample analysis and the accuracy of the proposed biosensor was examined by utilizing the standard addition technique. The $\mathrm{CDH} 22$ protein is present in human serum at $\mathrm{ng} / \mathrm{mL}$. Therefore, the human serum samples were diluted 100000 times by using PBS buffer. As observed in Table 1, the recovery ranges were from 99.16 to. $101.94 \%$, that confirmed the applicability of the biosensor for $\mathrm{CDH} 22$ antigen determination.

\section{Conclusion}

In this study, an impedimetric immunosensor was successfully introduced by using disposable ITO sheet for $\mathrm{CDH} 22$ biomarker detection. This sensitive and specific immunosensor was developed by immobilizing antiCDH 22 antibody onto CPTMS modified ITO electrode. Step-by-step modification process and the immunosensing process was followed by using electrochemical (CV, EIS) and morphological (SEM and AFM) techniques. Under optimum experimental conditions, the developed immunosensor displayed a selective detection of $\mathrm{CDH} 22$ cancer biomarker. In addition, our proposed method exhibited a highly sensitive and selective determination of $\mathrm{CDH} 22$ antigen with a detection limit of 9

Table 1. Results of human serum samples.

\begin{tabular}{|c|c|c|c|c|c|}
\hline Sample & $\begin{array}{c}\text { Found by the bio- } \\
\text { sensor } \\
(\mathrm{pg} / \mathrm{mL})\end{array}$ & $\begin{array}{c}\text { Added CDH } 22 \\
\text { amount } \\
(\mathrm{pg} / \mathrm{mL})\end{array}$ & Total found & \% Recovery & $\begin{array}{l}\text { \% Relative } \\
\text { difference }\end{array}$ \\
\hline $\begin{array}{l}\text { Human } \\
\text { Serum } 1\end{array}$ & 0.50 & 0.2 & 0.72 & 101.94 & 1.94 \\
\hline $\begin{array}{l}\text { Human } \\
\text { Serum } 2\end{array}$ & 0.68 & 0.2 & 0.88 & 100.57 & 0.57 \\
\hline $\begin{array}{l}\text { Human } \\
\text { Serum } 3\end{array}$ & 0.82 & 0.2 & 1.03 & 101.41 & 1.41 \\
\hline $\begin{array}{l}\text { Human } \\
\text { Serum } 4\end{array}$ & 0.83 & 0.2 & 1.04 & 101.00 & 1.00 \\
\hline $\begin{array}{l}\text { Human } \\
\text { Serum } 5\end{array}$ & 0.52 & 0.2 & 0.72 & 99.16 & -0.84 \\
\hline
\end{tabular}


$\mathrm{fg} / \mathrm{mL}$ and a linear range from $0.03 \mathrm{pg} / \mathrm{mL}$ to $3 \mathrm{pg} / \mathrm{mL}$ The success of the proposed biosensor in human serum samples analysis illustrated that this biosensor was a simple, cost-effective, selective and sensitive platform for determination of biomarkers. This proposed immunosensor provided simple tool for biomarker detection in clinical applications.

\section{References}

1. J. Duraiyan, R. Govindarajan, K. Kaliyappan, M. Palanisamy, Applications of immunohistochemistry, J. Pharm. BioAllied Sci., 4 (2012) S307.

2. D. Shin, N. Vigneswaran, A. Gillenwater, R. Richards-Kortum, Advances in fluorescence imaging techniques to detect oral cancer and its precursors, Future Oncol., 6 (2010) 1143 1154.

3. A. Gündoğdu, E.B. Aydın, M.K. Sezgintürk, A novel electrochemical immunosensor based on ITO modified by carboxyl-ended silane agent for ultrasensitive detection of MAGE-1 in human serum, Anal. Biochem., 537 (2017) 84-92.

4. E.B. Aydın, M. Aydın, M.K. Sezgintürk, Highly sensitive electrochemical immunosensor based on polythiophene polymer with densely populated carboxyl groups as immobilization matrix for detection of interleukin $1 \beta$ in human serum and saliva, Sens. Actuator. B, 270 (2018) 18-27.

5. E.B. Aydın, M. Aydın, M.K. Sezgintürk, Electrochemical immunosensor based on chitosan/conductive carbon black composite modified disposable ITO electrode: An analytical platform for p53 detection, Biosen. Bioelectron., 121 (2018) 80-89.

6. J. Zhou, J. Li, J. Chen, Y. Liu, W. Gao, Y. Ding, Over-expression of $\mathrm{CDH} 22$ is associated with tumor progression in colorectal cancer, Tumor Biol., 30 (2009) 130-140.

7. E. Martín-Sánchez, S. Mendaza, A. Ulazia-Garmendia, I. Monreal-Santesteban, A. Córdoba, F. Vicente-García, I. Blanco-Luquin, S. De La Cruz, A. Aramendia, D. GuerreroSetas, $\mathrm{CDH} 22$ hypermethylation is an independent prognostic biomarker in breast cancer, Clin. Epigenet., 9 (2017) 7.

8. B. Piche, S. Khosravi, M. Martinka, V. Ho, G. Li, CDH22 expression is reduced in metastatic melanoma, Am. J. Cancer Res., 1 (2011) 233.

9. M. Aydın, E.B. Aydın, M.K. Sezgintürk, Electrochemical immunosensor for $\mathrm{CDH} 22$ biomarker based on benzaldehyde substituted poly (phosphazene) modified disposable ITO electrode: A new fabrication strategy for biosensors, Biosens. Bioelectron., 126 (2019) 230-239.

10. X.R. Cheng, B.Y. Hau, T. Endo, K. Kerman, Au nanoparticlemodified DNA sensor based on simultaneous electrochemical impedance spectroscopy and localized surface plasmon resonance, Biosens. Bioelectron., 53 (2014) 513-518.

11. E.B. Aydın, M.K. Sezgintürk, Indium Tin Oxide (ITO): A promising material in biosensing technology, TrAC, Trends Anal. Chem., 97 (2017) 309-315.

12. C.M. Pandey, S. Dewan, S. Chawla, B.K. Yadav, G. Sumana, B.D. Malhotra, Controlled deposition of functionalized silica coated zinc oxide nano-assemblies at the air/water interface for blood cancer detection, Anal. Chim. Acta, 937 (2016) 29-38
13. S. Kumar, S. Kumar, S. Tiwari, S. Augustine, S. Srivastava, B.K. Yadav, B.D. Malhotra, Highly sensitive protein functionalized nanostructured hafnium oxide based biosensing platform for non-invasive oral cancer detection, Sens. Actuators, B, 235 (2016) 1-10.

14. I. Tiwari, M. Singh, C.M. Pandey, G. Sumana, Electrochemical genosensor based on graphene oxide modified iron oxidechitosan hybrid nanocomposite for pathogen detection, Sens. Actuators, B, 206 (2015) 276-283.

15. A. Sharma, D. Baral, H. Bohidar, P.R. Solanki, Oxalic acid capped iron oxide nanorods as a sensing platform, Chem.Biol. Interact., 238 (2015) 129-137.

16. A. Singh, M. Choudhary, M. Singh, H. Verma, S.P. Singh, K. Arora, DNA functionalized direct electro-deposited gold nanoaggregates for efficient detection of Salmonella typhi, Bioelectrochemistry, 105 (2015) 7-15.

17. A.K. Yagati, J.C. Pyun, J. Min, S. Cho, Label-free and direct detection of $\mathrm{C}$-reactive protein using reduced graphene oxide-nanoparticle hybrid impedimetric sensor, Bioelectrochemistry, 107 (2016) 37-44.

18. L. Yang, Y. Li, AFM and impedance spectroscopy characterization of the immobilization of antibodies on indium-tin oxide electrode through self-assembled monolayer of epoxysilane and their capture of Escherichia coli O157: H7, Biosens. Bioelectron., 20 (2005) 1407-1416.

19. M.B. dos Santos, S. Azevedo, J. Agusil, B. Prieto-Simon, C. Sporer, E. Torrents, A. Juárez, V. Teixeira, J. Samitier, Labelfree ITO-based immunosensor for the detection of very low concentrations of pathogenic bacteria, Bioelectrochemistry, 101 (2015) 146-152

20. E.B. Aydın, M. Aydın, M.K. Sezgintürk, A highly sensitive immunosensor based on ITO thin films covered by a new semi-conductive conjugated polymer for the determination of TNF $\alpha$ in human saliva and serum samples, Biosens. Bioelectron., 97 (2017) 169-176.

21. S. Komathi, A.I. Gopalan, K.P. Lee, Fabrication of a novel layer-by-layer film based glucose biosensor with compact arrangement of multi-components and glucose oxidase, Biosens. Bioelectron., 24 (2009) 3131-3134.

22. W. Chu, Q. Zhou, S. Li, W. Zhao, N. Li, J. Zheng, Oxidation and sensing of ascorbic acid and dopamine on self-assembled gold nanoparticles incorporated within polyaniline film, Appl. Surf. Sci., 353 (2015) 425-432.

23. N. Prabhakar, Z. Matharu, B. Malhotra, Polyaniline LangmuirBlodgett film based aptasensor for ochratoxin A detection, Biosens. Bioelectron., 26 (2011) 4006-4011.

24. M. Ozmen, K. Can, M. Ersoz, Immobilization of albumin on indium-tin oxide (ITO) surface via isocyanate linkage, J. Electroanal. Chem., 633 (2009) 228-234.

25. M.Ç. Canbaz, M.K. Sezgintürk, Fabrication of a highly sensitive disposable immunosensor based on indium tin oxide substrates for cancer biomarker detection, Anal. Biochem., 446 (2014) 9-18.

26. M. Khan, X. Liu, J. Zhu, F. Ma, W. Hu, X. Liu, Electrochemical detection of tyramine with ITO/APTES/ErGO electrode and its application in real sample analysis, Biosens. Bioelectron., 108 (2018) 76-81.

27. M.Z.H. Khan, Effect of ITO surface properties on SAM modification: A review toward biosensor application, Cogent Engineering, 3 (2016) 1170097.

28. H. Törer, E.B. Aydın, M.K. Sezgintürk, A label-free electrochemical biosensor for direct detection of RACK 1 by using disposable, low-cost and reproducible ITO based electrode, Anal. Chim. Acta, 1024 (2018) 65-72. 
29. D. Guo, M. Zhuo, X. Zhang, C. Xu, J. Jiang, F. Gao, Q. Wan, Q. $\mathrm{Li}, \mathrm{T}$. Wang, Indium-tin-oxide thin film transistor biosensors for label-free detection of avian influenza virus H5N1, Anal. Chim. Acta, 773 (2013) 83-88.

30. A.K. Yagati, T. Lee, J. Min, J.-W. Choi, Electrochemical performance of gold nanoparticle-cytochrome c hybrid interface for $\mathrm{H}_{2} \mathrm{O}_{2}$ detection, Colloids Surf. B, 92 (2012) 161 167.

31. E. Bahadır, M. Sezgintürk, Label-free, ITO-based immunosensor for the detection of a cancer biomarker: Receptor for Activated C Kinase 1, Analyst, 141 (2016) 5618 5626.

32. E.B. Aydın, M.K. Sezgintürk, A sensitive and disposable electrochemical immunosensor for detection of SOX2, a biomarker of cancer, Talanta, 172 (2017) 162-170.

33. M.N.S. Karaboğa, M.K. Sezgintürk, A novel silanization agent based single used biosensing system: Detection of C-reactive protein as a potential Alzheimer's disease blood biomarker, J. Pharm. Biomed. Anal., 154 (2018) 227-235.

34. C. Haensch, S. Hoeppener, U.S. Schubert, Chemical modification of self-assembled silane based monolayers by surface reactions, Chem. Soc. Rev., 39 (2010) 2323-2334.

35. J. Muñoz, R. Montes, M. Baeza, Trends in electrochemical impedance spectroscopy involving nanocomposite transducers: Characterization, architecture surface and biosensing, TrAC, Trends Anal. Chem., 97 (2017) 201-215.

36. E.B. Aydın, M.K. Sezgintürk, A disposable and ultrasensitive ITO based biosensor modified by 6-phosphonohexanoic acid for electrochemical sensing of IL-1 $\beta$ in human serum and saliva, Anal. Chim. Acta, 1039 (2018) 41-50.

37. M. Aydın, E.B. Aydın, M.K. Sezgintürk, A Disposable Immunosensor Using ITO Based Electrode Modified by a Star-Shaped Polymer for Analysis of Tumor Suppressor Protein p53 In Human Serum, Biosens. Bioelectron., 107 (2018) 1-9.

38. X.Y. Zhang, L.Y. Zhou, H.Q. Luo, N.B. Li, A sensitive and labelfree impedimetric biosensor based on an adjunct probe, Anal. Chim. Acta, 776 (2013) 11-16.
39. M. Labib, S. Martić, P.O. Shipman, H.B. Kraatz, Electrochemical analysis of HIV-1 reverse transcriptase serum level: Exploiting protein binding to a functionalized nanostructured surface, Talanta, 85 (2011) 770-778.

40. A.S. Bandarenka, Exploring the interfaces between metal electrodes and aqueous electrolytes with electrochemical impedance spectroscopy, Analyst, 138 (2013) 5540-5554.

41. M. Labib, P.O. Shipman, S. Martić, H.B. Kraatz, Towards an early diagnosis of HIV infection: an electrochemical approach for detection ofHIV-1 reverse transcriptase enzyme, Analyst, 136 (2011) 708-715.

42. M. Behpour, S.M. Ghoreishi, E. Honarmand, M. SalavatiNiasari, Comparative electrochemical study of new selfassembled monolayers of 2-\{[(Z)-1-(3-furyl) methylidene] amino\}-1-benzenethiol and 2 -\{[(2-sulfanylphenyl) imino] methyl\} phenol for determination of dopamine in the presence of high concentration of ascorbic acid and uric acid, Analyst, 136 (2011) 1979-1986.

43. S. Wang, Y. Zhang, J. Yu, X. Song, S. Ge, M. Yan, Application of indium tin oxide device in gold-coated magnetic iron solid support enhanced electrochemiluminescent immunosensor for determination of carcinoma embryonic antigen, Sens. Actuators B, 171-172 (2012) 891-898.

44. L. Alfonta, A. Bardea, O. Khersonsky, E. Katz, I. Willner, Chronopotentiometryand Faradaic impedance spectroscopy as signal transduction methods for the biocatalytic precipitation of an insoluble product on electrode supports: routes for enzyme sensors, immunosensors and DNA sensors, Biosens. Bioelectron., 16 (2001) 675-687.

45. Y. Huang, M.C. Bell, I.I. Suni, Impedance biosensor for peanut protein Ara h 1, Anal. Chem., 80 (2008) 9157-9161. 